\title{
The impact of smart tablets use in the mobile learning environment upon learning outcomes in football for students in the second stage of basic education "Dr/ Ahmed Shawky Mohamed Mohamed
} mobile learning is characterized by a friendly environment because the lessons and lectures are received through mobile phones, which do not require physical effort or a specific environment in which the learners are unrestricted. Bouman or a specific place. (16: 86)

Moving learning through smart tablets is a real and practical translation of the philosophy of distance learning that expands the educational opportunities of individuals and reduces their cost in comparison with traditional education systems as a philosophy that affirms the right of individuals to take advantage of educational opportunities that are available and time-bound. And not limited to a specific level or type of education, where the learner learns according to the capacity and ability and speed of learning and according to the previous experience and skills, and even the success in providing educational service suitable for some of the applicants of such a service,

And It is rooted in the consolidation of individual or self-education, which contributes to the translation of the concept of democracy education into reality scenes. (14: 82)

Smart tablets can be used and used in the education system through their own technologies or services that can provide many benefits to the learning process and offer new opportunities for traditional learning in the classroom as well as lifelong learning outside these classrooms. (17: 56)

And the traditional methods used in education depends on one source of knowledge is the explanation by the teacher and then the presentation of the model

Assistant Professor, Department of Curriculum and Instruction, Faculty of Physical Education, Benha University 
without the least actual participation of students in the integration of some educational and technological means to improve the educational process and when using these technological methods,

The teaching moves from methods based on the negative learner to modern methods developed And move the educational process from the teacher to the learner and the role of the teacher is guidance and guidance as it facilitates the process of education and reduce the learning time,

Which leads to increased effectiveness and efficiency in learning and refers Ahmed Fahim Badr (2012), citing Tracy ( 2004) that a person can remember $20 \%$ of what he hears and remember $40 \%$ of what he hears and see, but if he heard and saw and work, this ratio rises to $70 \%$.

While this percentage increases in the case of human interaction with what he learns through these modern methods (3:15)

Despite the importance of the use of smart tablets in the field of mobile learning and its effective role, but the researcher did not find studies have addressed the use of smart tablets in the mobile learning environment in the outcomes of learning in football for students of the second cycle of basic education to the knowledge

\section{Research Objective:}

The research aims to identify "the impact of the use of smart tablets in the mobile learning environment on learning outcomes in football for students of the second cycle of basic education

\section{-Research hypotheses}

-There are statistically significant differences between the pre and post measurements of the experimental group on learning outcomes in football in favor of dimension measurements.

-There are statistically significant differences between the pre and post measurements of the control group on learning outcomes in football in favor of dimension measurements.

-There were statistically significant differences in the learning outcomes in football between the experimental group and the control group in 
the dimension measurements for the experimental group.

\section{-Search Definitions:}

Mobile Learning:

Is a pattern of elearning, calling for the use of portable devices and devices to provide a new type of learning that is flexible and appropriate to the current technological developments? (56:13)

Tablet PC -

Is the middle state between laptops and cell phones, they come as a compromise between them, many of us did not satisfy the size of the cellular screen to enjoy browsing or watching videos, and find that the other large laptops when moving from place to place or somewhat heavy, and here arose the idea The tablets are a middle state between both. "(124: 4)

Search:

First: Research Methodology

The researcher used the experimental semiexperimental method to design two groups, one of which is experimental and the other by applying the post pre measurements for each group to suit the nature of the research.

\section{Third: Society and Research Sample:}

The research community consists of students of the second grade preparatory school of modern pioneers in the administration of Benha educational in the province of Qalyoubia for the academic year (2017 - 2018), the number of (215) students, and was selected sample random search of students in the second grade preparatory school at the modern school, The total number of students was 60 , with a percentage of $27.9 \%$. They were divided into two groups, one experimental and the other one, each with 30 students, in addition to 20 students for the survey.

\section{Homogenization of the research sample:}

To ascertain the occurrence of the research sample under the natural curve and then the distribution of the normal using the coefficients of the torsion to find a homogenous factor of the basic and experimental study variables, which is shown in Table (1)

Table (1) 
Homogeneity of the research community

\begin{tabular}{|c|c|c|c|c|c|}
\hline Variables & $\begin{array}{c}\text { Measure } \\
\text { unit }\end{array}$ & SMA & $\begin{array}{l}\text { standard } \\
\text { deviation }\end{array}$ & Mediator & $\begin{array}{c}\text { Torsion } \\
\text { coefficient }\end{array}$ \\
\hline Age & Year & 13.16 & 13.07 & 0.29 & 2.69 \\
\hline Height & $\mathrm{Cm}$ & 146.63 & 146.00 & 3.28 & 1.03 \\
\hline Weight & $\mathrm{Kg}$ & 44.19 & 45.00 & 2.89 & 1.46- \\
\hline $\begin{array}{l}\text { Numbered } \\
\text { circuits }\end{array}$ & $\mathrm{S}$ & 12.66 & 12.68 & 0.93 & $0.20-$ \\
\hline $\begin{array}{l}\text { Wide jump } \\
\text { from stability. }\end{array}$ & $\mathrm{Cm}$ & 158.55 & 157.00 & 8.47 & 0.41 \\
\hline $\begin{array}{l}\text { Running thirty } \\
\text { meters from a } \\
\text { moving start }\end{array}$ & $\mathrm{S}$ & 6.69 & 6.69 & 0.25 & $0.32-$ \\
\hline $\begin{array}{l}\text { Running and } \\
\text { rotation }\end{array}$ & $\mathrm{S}$ & 14.66 & 14.66 & 0.32 & 1.95 \\
\hline $\begin{array}{l}\text { Pass the ball on } \\
\text { the wall of the } \\
\text { block }\end{array}$ & No & 7.05 & 7.00 & 1.10 & 0.72 \\
\hline $\begin{array}{l}\text { Accuracy of } \\
\text { passing the ball } \\
\text { to the foot }\end{array}$ & Degree & 0.74 & 1.00 & 0.55 & 0.08 \\
\hline $\begin{array}{l}\text { Running the } \\
\text { ball around the } \\
\text { circle }\end{array}$ & $\mathrm{S}$ & 19.05 & 19.00 & 1.10 & 0.83 \\
\hline $\begin{array}{l}\text { kick the ball } \\
\text { with the head }\end{array}$ & Degree & 0.76 & 1.00 & 0.60 & 0.14 \\
\hline $\begin{array}{l}\text { The cognitive } \\
\text { test }\end{array}$ & Degree & 14.9 & 0.9 & 15 & $0.3-$ \\
\hline
\end{tabular}
torsion of "age, height, weight, physical and skill variables and Fourth: Means of collecting data cognitive test" were limited to $( \pm 3)$ where the values ranged from (1.49 to 2.69) Rates "of the selected variables" in question "and thus occur under

The researcher relied on collecting the information and data related to this research to the following tools and tools: - Instruments and tools used in research: 
- Resistameter to measure the length of the body measured in centimeters.

- Medical balance to measure weight in kilograms. PC

- Stopwatch (for measuring time)- Measuring tape (measuring distance)

- Mobil (android)

- Expert feedback form:

- An expert survey on the application of smart tablets in the mobile learning environment and its scientific content (7)

- Tests used:

- Physical tests: Attachment (2)

- The following physical tests were identified.

- Test the enemy 30 meters from the moving start to measure speed. (9: 363, 364)

-Test run and turn right to measure agility. (8: 58)

- Stability test of the stability of the muscles of the legs (9: 363,364 )

- Test circuit numbered to measure the compatibility of men and eyes. (10: 60)

- Test pass the ball on the wall of the resistor during $30 \mathrm{w}$ to measure accuracy. (9: 363, 364)

- Skills tests for the skills in question: Attachment (3)
- The following tests were identified:

- Test the accuracy of passing the ball in the foot between the two chairs to measure the accuracy of the scroll. (6:50)

- Test hit the ball with the head to measure the accuracy of passing the ball head to a specific place. (10: 69)

- Test ball run around a circle to measure the ability to control the ball while running in a curve line. (6: 53)

- Scientific procedures for the tests in question: Attachment (1)

-Test of cognitive achievement: Annex (5)

- The researcher used the cognitive test prepared by Ahmed Shawki Mohamed (2015) (1) and consists of (40) words distributed on the first axis: the legal side and the number of words (15) words, and the second axis: the technical aspect of football skills in question (25) words. This test was applied by the same age stage

- Scientific Experiments of the Test Cognitive Achievement: Attachment (1)

- The researcher found the scientific procedures for the 
test cognitive achievement: Annex (5)

- A questionnaire and emotional impressions of students about the use of smart tablets in the mobile learning environment: Attachment (7)

- Tutorial using smart tablets in the mobile learning environment (researcher's preparation): Attachment 10

- The researcher reviewed a number of references and reference studies that dealt with how to build the learning program through mobile learning only, and mobile learning using smart tablet applications or smart phones such as Schuler (Shuler (2012), Chu (2014) "Ahmed Fahim Badr" (2012) 3, "Ahmed Abdel Moneim Mohamed (2013), Mahmoud Mahmoud Awad (2014) (11)," and Walaa Mohammed Kamel al-Abd (2017) (20), and the researcher designed the program Educational system commensurate with the characteristics and trends and needs of this stage, which works to select the best programs that help the researcher to build the application and how to use it by smart tablets
- Implementation of the basic experience:

- Pre measurements

-The pre measurements were made in the technical variables and cognitive achievement on Tuesday, 7/3/2017

- Apply basic search experience:

- The researcher applied the basic research experiment in the period from Sunday, $12 / 3 / 2017$ to Wednesday, $19 / 4 / 2017$, at (6) weeks once a week for 90 minutes at a time. The experimental experiment was applied to the experimental group. Has implemented the traditional program.

\section{Control group:}

- The control group was subjected to the traditional program (verbal explanation and performance of the practical model) the following day of application of the experimental group.

- The experimental group:

- The experimental group was subjected to the educational program which contains smart tablets in the mobile learning environment (6) weeks once a week for 90 minutes at a time.

- Dimension measurements: 
- Post measurements were carried out in the basic research sample in the technical variables and the cognitive test on Thursday 20/4/2017.

\section{Statistical treatments:}

- The researcher used the statistical treatments suitable for the nature of the research using the program: Statistical Package for Social Sciences

Table (2)

The significance of the assumptions between the averages of the pre and post measurements of the experimental group In the technical tests of the sample in question $\mathrm{N}=30$

\begin{tabular}{|c|c|c|c|c|c|c|c|}
\hline \multirow[t]{2}{*}{ Tests } & \multirow{2}{*}{$\begin{array}{c}\text { Measure } \\
\text { unit }\end{array}$} & \multicolumn{2}{|c|}{ Pre measures } & \multicolumn{2}{|c|}{ Post measures } & \multirow{2}{*}{$\begin{array}{c}\text { The } \\
\text { difference } \\
\text { between } \\
\text { the two } \\
\text { averages }\end{array}$} & \multirow{2}{*}{$\begin{array}{c}T \\
\text { value }\end{array}$} \\
\hline & & SMA & $\begin{array}{l}\text { standard } \\
\text { deviation }\end{array}$ & SMA & $\begin{array}{l}\text { standard } \\
\text { deviation }\end{array}$ & & \\
\hline $\begin{array}{l}\text { Accuracy } \\
\text { of } \\
\text { passing } \\
\text { the ball } \\
\text { to the } \\
\text { foot }\end{array}$ & Degree & 0.67 & 0.48 & 2.77 & 0.50 & $2.10-$ & $21.00^{*}$ \\
\hline $\begin{array}{l}\text { Running } \\
\text { the ball } \\
\text { around } \\
\text { the circle }\end{array}$ & S & 19.32 & 0.99 & 16.23 & 0.76 & 3.10 & $11.85^{*}$ \\
\hline $\begin{array}{l}\text { kick the } \\
\text { ball with } \\
\text { the head }\end{array}$ & Degree & 0.83 & 0.70 & 1.83 & 0.38 & $1.00-$ & $7.37 *$ \\
\hline $\begin{array}{l}\text { The } \\
\text { cognitive } \\
\text { test }\end{array}$ & Degree & 14,93 & 0,907 & 28,60 & 1,22 & 13,66 & $47,28 *$ \\
\hline
\end{tabular}

The value of "T" in the table at the degree of freedom (2) and the level of moral $(0.05)=1.73$

Table (9) shows that there are statistically significant differences between the pre and post measurements
(SPSS) Statistical package for the Social Science, the following statistical treatments were used:

- SMA.- Broker- the standard deviation.. correlation coefficient "Pearson".- Test (T)

- Torsion coefficient

- View and discuss the results: 
the value (t) calculated is greater than the tabular value.

The researcher returns this result to the experimental research sample to the effect of smart tablets in the mobile learning environment, and the many advantages that these applications have to serve the students' learning, and contribute to the improvement of their knowledge and mobility level, where easy to carry smart tablets and transfer from one place to another, The presence of a camera that helps students to use it in the documentation at work, and the appropriate size that makes it easy for students to browse and see the practical models and the correct technical performance of the skills of football in question, in addition to providing multiple means to represent the content and provide multiple options Of pupils, and different ways to express knowledge texts, and quick access to information and effective smooth browsing, in addition to the possibility of loading programs and applications without the complexity of 0

Walaa Mohammed Kamel (2017), quoting Huber and Sabrina (2012), affirms that tablets will transform the educational task into a permanent function that is not related to time or place. Tablets can also contain textbooks and maintain them The tablet has become a tool for entering the ever-evolving technological education stage, encouraging students to self-learn, and facilitating new teaching methods such as participatory learning, collaborative learning and distance learning. (15: 18)

The researcher explains that the means used in the research is the property of the student at any time and any place can access the scientific content at any time, before, during and after the educational unit, which leads to a cycle to increase cognitive achievement.

This finding is consistent with the results of the study of Ahmed Abdel Moneim Mohamed (2013), Mahmoud Ahmed Desouki (2015), and Walaa Mohammed Kamel (2017). 15 It was pointed out that the use of learning Mobile through smart phones and smart tablets has a positive impact in the education of motor skills and 
development aspects and scientific concepts under their research. Thus, the first hypothesis is fulfilled

"There are statistically significant differences between the pre and post measurements of the experimental group on learning outcomes in football in favor of distance measurements"

Table (3)

Indication of differences between the mean and post measurements of the control group In the technical tests of the sample in question $\mathbf{N}=\mathbf{3 0}$

\begin{tabular}{l|c|c|c|c|c|c|c}
\hline \hline \multirow{2}{*}{ Tests } & \multirow{2}{*}{$\begin{array}{c}\text { Measure } \\
\text { unit }\end{array}$} & \multicolumn{2}{|c|}{ Pre measures } & \multicolumn{2}{|c|}{ Post measures } & $\begin{array}{c}\text { The } \\
\text { difference } \\
\text { between } \\
\text { the two } \\
\text { averages }\end{array}$ & $\begin{array}{c}\text { T } \\
\text { value }\end{array}$ \\
\cline { 3 - 7 } & SMA & $\begin{array}{c}\text { standard } \\
\text { deviation }\end{array}$ & SMA & $\begin{array}{c}\text { standard } \\
\text { deviation }\end{array}$ & & \\
\hline \hline $\begin{array}{l}\text { Accuracy } \\
\text { of } \\
\text { passing } \\
\text { the ball } \\
\text { to the } \\
\text { foot }\end{array}$ & Degree & 0.63 & 0.56 & 1.87 & 0.73 & $1.23-$ & $6.50^{*}$ \\
\hline $\begin{array}{l}\text { Running } \\
\text { the ball } \\
\text { around } \\
\text { the circle }\end{array}$ & S & 19.17 & 1.02 & 17.87 & 1.06 & 1.30 & $5.03^{*}$ \\
\hline $\begin{array}{l}\text { kick the } \\
\text { ball with } \\
\text { the head }\end{array}$ & Degree & 0.57 & 0.50 & 1.57 & 0.50 & $1.00-$ & $6.95^{*}$ \\
\hline $\begin{array}{l}\text { The } \\
\text { cognitive } \\
\text { test }\end{array}$ & Degree & 15 & 0,787 & 22,23 & 1,06 & 7,33 & $30,36^{*}$ \\
\hline \hline
\end{tabular}

Tabular value at a significant level of 0.05 and freedom degree of $19=1.72$ Table (3) shows the control group, since the statistically significant differences between the pre and post measurements in favor of the dimension measurements in the technical tests and the cognitive test of calculated value (t) is greater than the tabular value.

The researcher believes that this improvement is due to the characteristics of the method (orders) and the focus 
of the importance of the presence of the teacher, which gives a clear idea of how to perform the right skill through the verbal presentation of the skill that contains an explanation of the importance of skill and then give a model which makes it more effective As well as the ability of the teacher to discover and fix problems before they prove and become

It also impairs the correct performance of the skills to be learned and provides the student with an opportunity to learn, which has a positive effect on the proficiency and efficiency of the performance, as well as the provision of information and knowledge when learning these skills during the period has helped to increase the knowledge and information of the students, which in turn helped to improve their level of cognitive achievement.

The researcher also attributes these real differences in the dimension measurements to the similarity of the educational program of the control group with the experimental group in terms of the educational environment, the possibilities and the time period. The learner's knowledge of the content of the skill performance of the motor skills helps to form the clear picture of these skills as well as the correct sequence of them. (1) Mahmoud Ahmed Desouki (2015) (11),

Sameh

Mahmoud Abdel-Aal (2016) (5) where he pointed out that the method of command showed a positive impact On the growth of physical and professional achievement Where the learner has the opportunity to learn by presenting a practical model of skill to be used for the method of presentation of theoretical information and commentary and criticism associated with the model.

Thus, the second hypothesis is fulfilled

"There are statistically significant differences between the pre and post measurements of the control group on learning outcomes in football in favor of dimension measurements" 
Table (4)

Indication of the differences between the measurements of the post measurements of the experimental and control groups In the technical tests of the sample in question $n=30$

\begin{tabular}{l|c|c|c|c|c|c|c}
\hline \hline Tests & \multirow{2}{*}{$\begin{array}{c}\text { Measure } \\
\text { unit }\end{array}$} & \multicolumn{2}{|c|}{ Experimental group } & \multicolumn{2}{|c|}{ Control group } & $\begin{array}{c}\text { The } \\
\text { difference } \\
\text { between } \\
\text { the two } \\
\text { averages }\end{array}$ & $\begin{array}{c}\text { T } \\
\text { value } \\
\text { deviation }\end{array}$ \\
\cline { 3 - 8 } & & & & & & & \\
\hline \hline $\begin{array}{l}\text { Accuracy } \\
\text { of } \\
\text { passing } \\
\text { the ball } \\
\text { to the } \\
\text { foot }\end{array}$ & Degree & 2.77 & 0.50 & 1.87 & 0.73 & 0.90 & $5.56^{*}$ \\
\hline $\begin{array}{l}\text { Running } \\
\text { the ball } \\
\text { around } \\
\text { the circle }\end{array}$ & $\mathrm{S}$ & 16.23 & 0.76 & 17.87 & 1.06 & $1.65-$ & $6.8 *^{*}$ \\
\hline $\begin{array}{l}\text { kick the } \\
\text { ball with } \\
\text { the head }\end{array}$ & Degree & 1.83 & 0.38 & 1.57 & 0.50 & 0.27 & $* 2.32$ \\
\hline $\begin{array}{l}\text { The } \\
\text { cognitive } \\
\text { test }\end{array}$ & Degree & 28,60 & 1,22 & 22,23 & 1,06 & 6,36 & $22,04 *$ \\
\hline \hline
\end{tabular}

The value of "T" in the table at the degree of freedom (38) and the level of moral $(0.05)=1.96$

Table (13) shows that statistically significant differences between the experimental and control groups are in favor of the experimental group in the skill level, since the calculated value (t) is greater than the tabular value.

The researcher attributed this apparent progress in the technical level of some of the football skills in the research group to the use of smart phones in the mobile learning

environment, which was through the educational program, which includes the presentation of skills to be learned through the smart tablets attractively and led to the vision of skills And the knowledge to be learned through the mobile phone clearly and easily in the representation several times, as the means used is the property of the student and this is the most important feature unlike other educational tools can be

Assiut Journal For Sport Science Arts 
used in educational programs, but not the researcher or researcher,

The main educational tool in this research is the property of the student through which the student can return the educational content and repeat several times at any time he wishes during the day during and before and after the educational unit and thus help in the process of learning and mastering skills and knowledge, and was introduced knowledge and information in an orderly manner It is also interesting to see the students' interaction with the educational program according to their ability and speed of absorption and learning, which led to the superiority of the experimental group to the control group that used the road $\mathrm{Ge}$ traditional based on the commentary and performance model

In addition, mobile learning provides a learning environment that takes into consideration the individual differences of students in a large and clear way, where students can receive scientific information in a manner that is appropriate to their audio and visual abilities, and works to achieve the educational goals to be achieved in less time and less effort, as well as having fun and motivation to learn and helps students In reliance on themselves

Schuler (2012) argues that intelligent learning is one type of learning in which learners use mobile devices, which include digital content for learning anywhere, anytime, such as PDAs, laptops, Wireless connectivity (184: 21)

Ally (2004) and Dogan, Bulent (2015) agree that mobile devices can make mobile teaching workable, and that interaction with touch screens on smartphones And tablets can allow students to process new information, and can transfer these devices and applications teaching materials as a virtual world, and can be used to provide educational materials for students, educational materials need to use multimedia strategies, rather than textual strategies, the goal of mobile learning is to provide An educational environment, which allows learners To learn at any time, anywhere, or from any device, thereby achieving a more creative learning process. (18:16), (170: 29), (38:28)

This result is consistent with the results of the study of Ahmed Abdel Moneim 
Mohamed (2013), Mahmoud Ahmad Desouki (2015), and Walaa Mohammed Kamel (2017). 15 They noted that mobile learning Using smart phones and smart tablets has an effective effect on improving the technical aspect of learners compared to the traditional way

Thus, the second hypothesis is fulfilled, which states

"There are statistically significant differences in the learning outcomes in football between the experimental group and the control group in the mean distance measurements for the experimental group"

The researcher attributed the improvement in the level of cognitive achievement of the experimental group students to the use of smart tablets in the mobile learning environment, including video, pictures, written texts, discussions, sentences on different devices.

All this led to intensive and unconventional information delivery, as well as presentation of the best models of the skills under study, how to properly teach different skills, evaluate students' performance, provide appropriate feedback, and provide information and knowledge related to skill content. And to chart the sound motor paths of the skills in question. The learning process has been enhanced and made more effective by using the learner for more than a sense as well as for the organized and interesting presentation of knowledge and information.

The researcher attributed this improvement to the presentation of knowledge and information in an organized and interesting way accompanied by illustrations and educational video files that make information related to the minds of students, which leads to the interaction of students with the educational program during the unit and try to retrieve the read information and performance methods that were seen for different skills according to individual abilities In learning, which led to the improvement of the experimental group from the control group (under study)

This is consistent with what was referred to by the loyalty of Mohammed Kamel (2017), quoting Azmi Gad Nabeel (2014). Mobile learning enables teachers to use it through the easy distribution of work to students. Students can easily interact with each other and with the teacher instead of 
sitting behind large screens; Mobile learning can be used anytime, anywhere and otherwise. It may solve the problem of students dropping out of school. Students who have dropped out of school can enjoy learning to use mobile learning, increase motivation, and commit students to learning if the student takes the device home. Any time he wants that You help him take responsibility. (16:15)

This result is consistent with the results of Carr (2013), Shaw Chu (2014), Ahmed Fahim Bader (2012), Mahmoud Ahmed Desouki (2015) , And "Walaa Mohammed Kamel" (2017) (15), who pointed out that there is a marked improvement in cognitive achievement through the use of smart tablets in the mobile learning environment to acquire knowledge and information, and that it is necessary to take advantage of this technology in universities and facilitate the use of tablets Smart in education because of its positive role in the educational process. And thus fulfills the third research hypothesis, which states:

"There are statistically significant differences in the learning outcomes in football between the experimental group and the control group in the mean distance measurements in favor of the experimental group"

\section{Table (5)}

\section{Opinions and emotional impressions of students in the experimental group towards use Use smart tablets in a mobile learning environment}

\begin{tabular}{|c|c|c|c|c|c|c|c|c|}
\hline \multirow{2}{*}{$\begin{array}{c}\text { Phrase } \\
\text { no }\end{array}$} & \multicolumn{2}{|c|}{ Agree } & \multicolumn{2}{|c|}{ To some extent } & \multicolumn{2}{|c|}{ Not agree } & \multirow[b]{2}{*}{ Ka 2} & \multirow{2}{*}{$\begin{array}{l}\text { The level of } \\
\text { statistical } \\
\text { significance } \\
\text { at the level } \\
\text { of } 0.05\end{array}$} \\
\hline & Frequency & percentage & Frequency & percentage & Frequency & percentage & & \\
\hline 1 & 24 & $\% 80$ & 3 & $\% 10$ & 3 & $\% 10$ & *29.4 & $\begin{array}{l}\text { In favor of } \\
\text { approvers }\end{array}$ \\
\hline 2 & 26 & $\% 86.7$ & 2 & $\% 6.67$ & 2 & $\% 6.7$ & *38.4 & $\begin{array}{l}\text { In favor of } \\
\text { approvers }\end{array}$ \\
\hline 3 & 3 & $\% 10$ & 3 & $\% 10$ & 24 & $\% 80.0$ & *29.4 & $\begin{array}{c}\text { In favor of } \\
\text { non-approvers }\end{array}$ \\
\hline 4 & 25 & $\% 83.3$ & 4 & 13.34 & 1 & $\% 3.3$ & *34.2 & $\begin{array}{l}\text { In favor of } \\
\text { approvers }\end{array}$ \\
\hline 5 & 24 & $\% 80.0$ & 4 & $\% 13.3$ & 2 & $\% 6.67$ & *29.6 & $\begin{array}{l}\text { In favor of } \\
\text { approvers }\end{array}$ \\
\hline 6 & 3 & $10 \%$ & 3 & $\% 10$ & $\% 24$ & $\% 80.0$ & 29.4 & $\begin{array}{c}\text { In favor of } \\
\text { non- } \\
\text { approvers }\end{array}$ \\
\hline
\end{tabular}


Follow Table (5)

Opinions and emotional impressions of students in the experimental group towards use Use smart tablets in a mobile learning environment

\begin{tabular}{|c|c|c|c|c|c|c|c|c|}
\hline \multirow{2}{*}{$\begin{array}{c}\text { Phrase } \\
\text { no }\end{array}$} & \multicolumn{2}{|c|}{ Agree } & \multicolumn{2}{|c|}{ To some extent } & \multicolumn{2}{|c|}{ Not agree } & \multirow[b]{2}{*}{ Ka 2} & \multirow{2}{*}{$\begin{array}{c}\text { The level of } \\
\text { statistical } \\
\text { significance } \\
\text { at the level } \\
\text { of } 0.05\end{array}$} \\
\hline & Frequency & percentage & Frequency & percentage & Frequency & percentage & & \\
\hline 7 & 3 & $10 \%$ & 2 & $\% 6.7$ & 25 & $\% 83.3$ & $* 29.4$ & $\begin{array}{c}\text { In favor of } \\
\text { non- } \\
\text { approvers }\end{array}$ \\
\hline 8 & 24 & $\% 80.0$ & 4 & $\% 13.3$ & 2 & $\% 6.67$ & $* 29.6$ & $\begin{array}{l}\text { In favor of } \\
\text { approvers }\end{array}$ \\
\hline 9 & 25 & $\% 83.3$ & 3 & $\% 10$ & 2 & $\% 6.7$ & $* 33.8$ & $\begin{array}{l}\text { In favor of } \\
\text { approvers }\end{array}$ \\
\hline 10 & 26 & $\% 86.7$ & 2 & $\% 6.7$ & 2 & $\% 6.7$ & $* 38.4$ & $\begin{array}{l}\text { In favor of } \\
\text { approvers }\end{array}$ \\
\hline 11 & 25 & $\% 83.3$ & 4 & $\% 13.3$ & 1 & $\% 3.3$ & $* 34.2$ & $\begin{array}{l}\text { In favor of } \\
\text { approvers }\end{array}$ \\
\hline 12 & 2 & $\% 6.67$ & 3 & $10 \%$ & 25 & $\% 83.3$ & $* 33.8$ & $\begin{array}{c}\text { In favor of } \\
\text { non- } \\
\text { approvers }\end{array}$ \\
\hline
\end{tabular}

The value of $\mathrm{Ka} 2$ is the tabular at a significance level of $0.05=5.99$

Table (5) shows that the views and impressions of the students in the experimental group that are approved and not accepted towards the terms of the survey questionnaire are statistically significant at 0.05 and for the approvers. This is an indicator of the use of smart tablets in the mobile learning environment. Increase the effectiveness of learning the skills of football under consideration

\section{Results:}

The proposed program using smart tablets in the mobile learning environment has a positive impact on learning the skills of football skills in the research group and improving the level of cognitive achievement.

The traditional method (verbal explanation and practical model) contributed to learning the skills of football in question, and has a positive effect on the acquisition of information and theoretical knowledge of the control group.

\section{Recommendations:}

-The use of smart tablets in the mobile learning environment for its effectiveness in learning and mastering the skills of football in search as well as cognitive achievement. 
-The necessity of appropriate recruitment of the techniques used in the teaching of football courses.

\section{References}

\section{1-Ahmed Abdel-Moneim}

Mohamed (2013): "A program using mobile learning and its effect on learning some gymnastics skills for smart school students in the light of information and communication technology", $\mathrm{PhD}$ thesis, Faculty of Physical Education, Tanta University

2-Ahmed Fahim Badr (2012): "The effectiveness of mobile learning using the SMS service in the development of awareness of some terms of technology education in the specialist technology education and the trend towards mobile learning," Journal of Faculty of Education, Volume (23), No. (90) Banha.

\section{3-Ahmed}

Shawqi

Mohammed (2014): the reality of reality technology and its impact on the level of performance of some basic motor skills and cognitive achievement in football for students in the preparatory stage Journal of Physical Education and Sports, No. (25) Faculty of Physical Education for Girls،

4- Ally, M., (2004): Using Learning Theories to Design Instruction for Mobile
Learning Devices. In J. Attewell and C. Savill-Smith (Eds.), Mobile Learning anytime everywhere: a book of papers from MLEARN (pp.58). London, UK: Learning and Skills Development Agency.

5- Carr, Jennie M. (2013): Incorporation of iPad into Fifth-grade Mathematics Instruction: A Focus on Mathematics Achievement., Dissertation Abstracts International Section A: Humanities and Social Sciences, 74 (1), 19-29

6- Chu, H., (2014): Potential Negative Effects of Mobile Learning on Students' Learning Achievement and Cognitive Load: A Format Assessment Perspective. Educational Technology \& Society, 17 (1), 332-344

7- Dogan, Bulent (2015): Integration of iPad in Higher Education: a Pilot Project., North American College, Housten, Texas, U.S.

8-Ghazi Youssef, Ibrahim Magdy Saleh, Mamdouh Saad, Agami Mohamed Agami, Mamdouh Ibrahim (2006): Modern trends in football training, Al-Zizi Computer Library, Zagazig

9-Jamal Abdulaziz AlSharhan (2001): e-book, eschool and virtual learning, Obeikan Library, Riyadh.

10-Litterst, G., (2013): How Do Mobile Devices and Apps Inspire and Facilitate your 
Teaching? Clavier Companion, 5 (5), 34-54

11-Mohammed Abdo Saleh, Mufti Ibrahim Hammad (1994): The basics of football, Dar Alam Knowledge, Cairo.

\section{2-Mahmoud}

Ahmed

Desouki (2015): "The Effect of

Mobile Learning on Cognitive Achievement and Some Kinetic Skills and Reducing Learning Concern in Handball for the Hearing Impaired", PhD Thesis, Faculty of Physical Education, Alexandria University.

13-Mohamed El Sayed Khalil (1999): tests and measurements in physical education, Faculty of Physical Education Mansoura University.

14-Mohamed Hassan Allawi and Mohamed Nasr El-Din Radwan (1995): the test of motor performance I 3, Dar AlFikr Al-Arabi, Cairo.

\section{5-Mohamed}

Hassanein

Sobhy

Measurement and Evaluation in Physical Education and Sport, 4, 1, Dar Al-Fikr AlArabi, Cairo.

\section{6-Mustafa}

Mohammed

Abdul Samie (2004):

Technology of education (concepts and applications) I 1, Dara Publishing, Amman.

17-Mustafa Mahmoud Awad (2014): "The effectiveness of the use of Keller strategy supported by mobile learning in the education of some basic skills of the weapon of the Blind", Master, Faculty of Physical Education, Tanta University.

18-Sameh Mahmoud Abdel Aal (2016): Building an electronic booklet for smart phones and its impact on learning some football skills for beginners in football, Journal of Physical Education and Sports Research, No. (19) Faculty of Physical Education for Boys, Banha University.

19- Shuler, C. ,(2012): "Pockets of Potential: Using Mobile Technologies to Promote Children's Learning". The Joan Ganze Cooney Center at Sesame Workshops. New York

\section{0-Training and Human} Development Unit (2012): "Mobile Learning - Training Package, Deanship of ELearning and Distance Learning", King Abdulaziz University.'

\section{1-Walaa Mohammed Kamel} Al - Abd (2017): The impact of mobile learning using smart tablets to learn the cognitive and technical aspects of abdominal crawling swimming, Journal of Physical Education and Sports Research, No. (21) Faculty of Physical Education for Boys, Banha University 